\title{
PSA Level Five to Ten
}

National Cancer Institute

\section{Source}

National Cancer Institute. PSA Level Five to Ten. NCI Thesaurus. Code C124829.

A blood concentration of prostate specific antigen between 5 and $10 \mathrm{ng} / \mathrm{mL}$. 